as Romney's research plan — are now likely to feature prominently in the election campaign. Murmurs about 'competitiveness' that have been around for years will gain new salience

Romney's rhetoric will resonate with many physical scientists and engineers. "We spend $\$ 30$ billion a year in the National Institutes of Health, and we lead the world in health-care products. In defence, we spend even more. We lead the world in defence products," he told the Detroit Economic Club on 14 January. "Why not also invest in energy and fuel technology right here in Michigan?" These sentiments come straight from the songsheet of the American Physical Society and its allies, which have long been pursuing a more modest proposal to double the amount the federal government spends on research in the physical sciences and engineering. But Romney's pledge of \$20 billion promises much more.

This isn't some hick candidate pulling numbers out of the air: a former chief executive of Bain \& Company, the Boston management consultancy, Romney knows what $\$ 20$ billion is. And precedents suggest that a specific, costed commitment such as this one - made in the heat of the primary campaign - will be hard to discard if the candidate who made it is actually elected.

Even so, there is something unreal about Romney's proposal. Notably, it was made as part of a speech outlining the fantasy that the US motor industry can bounce back from its current emaciated state. General Motors and Ford have had some three decades of notice from Toyota, Nissan and Honda that it is time to shape up, and have utterly squandered every opportunity to respond. Significantly, Romney allied his research pledge with a call for looser fuel-efficiency standards - the signature cause of the Detroit industry, which has repeatedly signed its own death warrant by resisting innovation at every turn.

Senator John McCain (Republican, Arizona), Romney's rival in Michigan, promised action on global warming and told voters that their old jobs aren't coming back - a message they probably didn't want to hear. There will clearly be political mileage in the sort of fixes Romney promised to Michigan last week. And as the United States' economic troubles deepen in this election year, there may be more snap prescriptions for industrial revival, some of them based on heavy federal investment in research and development.

That represents a promise and a threat for scientists and engineers whose disciplines stand to benefit. The promise is considerable. As US physical scientists
"As the United States' economic troubles deepen, there may be more snap prescriptions for industrial revival." have been arguing for years, their work can help bolster industrial competitiveness, directly and indirectly. Thankfully, there is an even broader consensus (now shared by Republican and Democrat presidential candidates) that energy research is under-funded.

But Romney's disingenuous \$20-billion pledge should be treated with scepticism. It is almost inconceivable that Congress would deliver that kind of money. Romney feebly suggested that it be diverted from federal job-training programmes, but these are scantily funded, and sure to grow, not contract, if recession arrives. And as for the justification of a comeback for Detroit, that particular movie ended decades ago and there will be no sequel.

\section{A little less Disneyland}

\section{DARPA should focus on its founding values.}

t is the ultimate playground for academics with big dreams: $\$ 3$ billion to do whatever you want, as long as it's in the interests of defending the United States. An open chequebook, and no peer review, has meant great success for the Pentagon's research wing, the 250-strong Defense Advanced Research Projects Agency (DARPA). Over the past half-century, it has been the place where the best and the brightest gather to crack some of the toughest nuts in the defence community: how to build radar-defying stealth aircraft; how to detect hostile missile launches; how to build the best satellite-navigation system so that soldiers can find their way. 'DARPA hard' is the phrase that's used - if it's not hard enough for DARPA to do, it's not worth the agency doing it.

DARPA's accomplishments are legendary, so much so that other areas of the government are hoping to mimic its success with their own DARPA spin-offs (see pages 390 and 403). This is not an easy task but not necessarily a bad idea; at the very least, some parts of the government not known for innovation might begin to think about technological issues from a creative and higher-risk standpoint. But what is the future of DARPA itself?

Its 50-year mark is as good a time as any to take stock. Like the rest of the United States, DARPA can no longer afford to operate under a cold-war mentality; the terrorist attacks of 11 September 2001 and their aftermath have dramatically restructured the country's national defence needs. DARPA stumbled badly in one of its first and most prominent responses to the attacks by setting up an invasive information-mining programme run by a man convicted of multiple felonies (later reversed on a technicality) relating to the Iran-Contra scandal of the 1980s.

Today, some of DARPA's activities remain firmly rooted in its cold-war research past, which led to the unmanned drones flying surveillance missions in Iraq. But, as was on show in a California Disneyland hotel last year, the agency's director, Anthony Tether, has also tried jazzing things up a bit, by sponsoring competitions such as the \$2-million 'grand challenge' robot car race. Even his critics note that Tether has managed to draw younger researchers into an agency whose stalwart backers are growing greyer every year.

Such approaches may be useful in helping the government think outside of the box. But DARPA must be careful not to stray too far down that path. The agency's future will depend in large part on the actions of Tether's successor: the position of DARPA director is a powerful one, with the ability to select programme managers and dispense money as he or she sees fit.

The agency's next director must take the agency back to basics, or risk losing the edge that comes from the inspired patronage of risky research. Above all, DARPA needs to concentrate more on projects that could lead to long-term pay-offs in the fight against terrorism, in ways we cannot yet imagine. 